\title{
Technical feasibility analysis of reservoir on agricultural area
}

\author{
Sulwan Permana ${ }^{1 *}$ \\ ${ }^{1}$ Sekolah Tinggi Teknologi Garut, Department of Civil Engineering, Jl. Mayor Syamsu No. 1, Garut 44151, Indonesia
}

\begin{abstract}
The availability of raw water is a major requirement to increase agricultural production, especially rice, as well as for domestic purposes for the community. One source of water is rivers used by communities to fill daily needs for both agricultural and other needs. This research is a survey research, conducted in Puspamukti Village, Subdistrict Cigalontang, Tasikmalaya Regency. With The purpose of knowing the feasibility of reservoir development. The source of water used at the research locus is from the river and several springs utilized by the community to irrigate the agricultural area of 750 ha. Based on topographical conditions, the area has a potential to be made into a reservoir that could be as a supply for domestic agricultural and water areas. The method of calculating the average rainfall of 2 rain posts is done by various return period, the calculation of dependable flow and water balance, and the design flood discharge. The watershed area is $6.4 \mathrm{~km}^{2}$. The maximum dependable flow is $0,6 \mathrm{~m}^{3} / \mathrm{sec}$. Based on the dependable flow, area that can be irrigated is only about 440 ha., and the domestic needs is about $9,1 \mathrm{lt} / \mathrm{sec}$. The reservoir development at the research locus is considered less feasible.
\end{abstract}

\section{Introduction}

Indonesia is known as a country that is rich in natural resources, this is because Indonesia is one of the countries that is passed by the equator, which includes it as a tropical country. As a tropical country, Indonesia has two climates so the agriculture sector becomes the prima donna of Indonesia's population. In 1984 Indonesia had made self-sufficiency in rice farmings that were marked with donations to needed countries. Also at that time the government promoted the transmigration program.

Although Indonesia is a rice producing country, it still needs to import rice from other countries. This is due to the increase of population, the change of function of wetland in productive areas, the increase of rice consumption per capita per year, and the decrease of rice production volume. In addition to meeting the shortage of domestic needs.

Along with the increase in population, the need for food, especially rice is increasing. For that reason, the government is trying to increase agricultural production, one of which is to expand new irrigation area or to create new irrigation system in the existing rice field area [1]. The contributions of climate fluctuations and human activities to streamflow change were determined quantitatively by comparing the natural streamflow with the observed value [2]. Drought is one of natural disaster occurrences that affect many life aspects such as agricultural and economy [3].

In an effort to support national development, the Ministry of Agriculture of the Republic of Indonesia through the Food Security Agency with its vision in 20152019 "The realization of food security through diversification of food, based on local resources on food sovereignty and self-sufficiency" [4]. To support the national food security program, the development of land agriculture is necessary in order to improve food production, especially rice, the increase of farmer's income, and fulfill the local consumption necessities. Water resources are fundamental to economic development, ecological environment improvement and social progress [5]. With conditions that exist in the area and in order to acknowledge whether the reservoir plan in the area is feasible to build or not, it is necessary to conduct the analysis of appropriateness technical development of reservoir. The purpose of this research is to study the technical feasibility of reservoir at the research location.

\section{Methodology}

Selection of proper methodology to analyze the field condition in order to obtain appropriate analysis results. Therefore, this analysis prepared several methodologies to be used, including secondary data collection that is in the form of rainfall data (at least 10 years), meteorology, discharge measurement data if simulation method is not used, geological data, watershed area, farming area, planting, population and land conditions in the upper reservoir. The location of the research is Puspamukti Village, Cigalontang Subdistrict, Tasikmalaya Regency [1]. While the required primary data is the existing channel width, and the reservoir location data acquired through field surveys. Another indispensable data is the measurement of the situation around the location.

The method of calculating the average rainfall with 2 rain stations (Gunung Satria and Cisolok station) [1] was

\footnotetext{
*Corresponding author: sulwanpermana $@$ sttgarut.ac.id
} 
calculated by the mean method of algebra and performed with various return periods. Around the site, there was no discharge measurements, so that the discharge calculations was done by a simulation of NRECA (National Rural Electric Cooperative Association). This method is used because the field conditions are flanked by hills and, there's a stream even several days after the rain stopped. The dependable flow is calculated based on NRECA method for the dependable flow irrigation water needs was taken $80 \%$ after being sorted from largest value to the smallest. Whereas for raw water was taken $90 \%$. The calculation of design flood discharge with different return periods is used to determine the elevation reservoir. Design flood calculation can be done with several methods such as rational, Weduwen, Melchior, unit hydrograph [6], Nakayasu, Gama, and Snyder method, the area of watershed is less than $100 \mathrm{~km}^{2}$. Flood frequency analysis method is traditionally used to determine the design flood [7]. Design of the spillway should be able to pass the design flood up to the limit [8]. The calculation of water requirement in the rice field is divided into 4 groups, the selection of water needs is used with 6 alternatives. Calculation of domestic demand for water is based on number of people in urban and rural areas, while the geometric formula is used for population projection. The calculation of surface area and reservoir volume is calculated based on the contour of the measurement result in the field.

\section{Result and discussion}

\subsection{Result}

The watershed area and land use conditions are an important parameter in calculating the discharge, the area of watershed is calculated based on topographic map, the measured watershed area, which is around $6.4 \mathrm{~km}^{2}$ [1]. Watershed map and rainfall data are used to derive the mean rainfall [9]. The average amount of precipitation calculated by means of an algebraic average is taken from 2 stations of rain measurement in the watershed area or around the area. The average annual rainfall for 10 years around the site is $3500 \mathrm{~mm} /$ year. The amount of design flood in this analysis used Weduwen's method, since the watershed area is less than $100 \mathrm{~km}^{2}$. Based on the rainfall, the design of flood at the reservoir plan location is $34 \mathrm{~m}^{3} / \mathrm{sec}, 36 \mathrm{~m}^{3} / \mathrm{sec}$ and $42 \mathrm{~m}^{3} / \mathrm{sec}$ for each return period of 20,25 and 50 years. Water availability depends on the amount of inflow to the reservoir [10].

The water requirement in paddy field for rice plant is calculated based on the rainfall R80 and effective rainfall, which is $0.7 \mathrm{R} 80$. The average of half-monhtly R80 is calculated in the order of the smallest to the largest, in which, in this calculation the R80 is $85 \mathrm{~mm} /$ half-month. While the average effective daily rainfall is $3.9 \mathrm{~mm} /$ day. Calculation of water requirement in rice field used by dependable flow is calculated by NRECA with parameter items, such as, average rainfall, initial moisture storage, soil moisture storage, excess moisture, reduction coefficient and other supporting data, maximum dependable debit about $0.6 \mathrm{~m}^{3} / \mathrm{sec}$ occurred in April, while the minimum of dependable debit is $0.04 \mathrm{~m}^{3} / \mathrm{sec}$ occurred in August . The existing rice field area is about 750 ha [1]. The need for net water in the rice fields (NFR= Net Field Requirement) is done with some alternatives, from the calculation of the maximum need for net water in the rice field around $1.35 \mathrm{lt} / \mathrm{sec} / \mathrm{ha}$, so that the area of rice fields that can irrigated is about 440 ha. Based on the discharge of irrigated rice fields that are not irrigated about 310 ha.

The surface area in the storage location calculated on the basis of contour is $5170 \mathrm{~m}^{2}$, while the reservoir volume is $7871 \mathrm{~m}^{3}$ [1] (Figure 1).

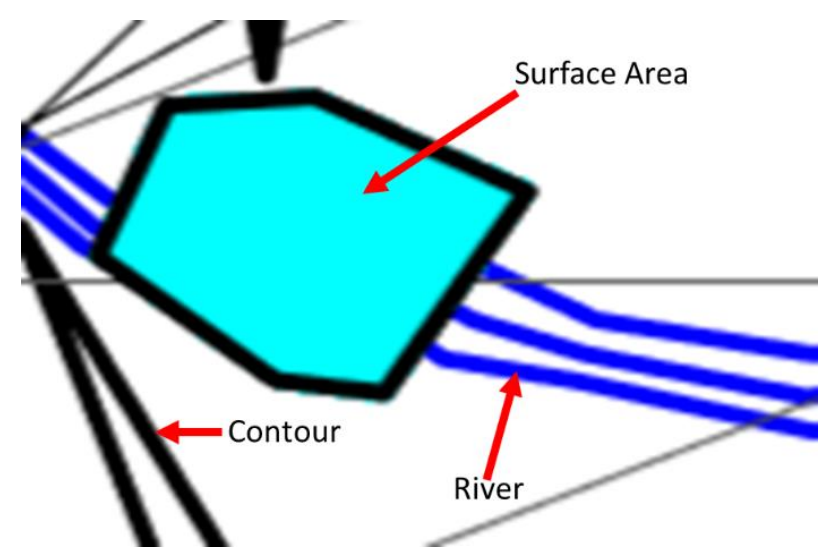

Fig. 1. Surface area [1].

The calculation of the surface area of the storage and the volume of the catch is based on field conditions and the estimated spillway height. The availability of water other than for irrigation purposes is also for the purposes domestic including the benefit of the community around the reservoir location. Water balance is needed to compare the level of irrigation water needs per half month with water availability at the source of the take with the area of rice field (Figure 2).

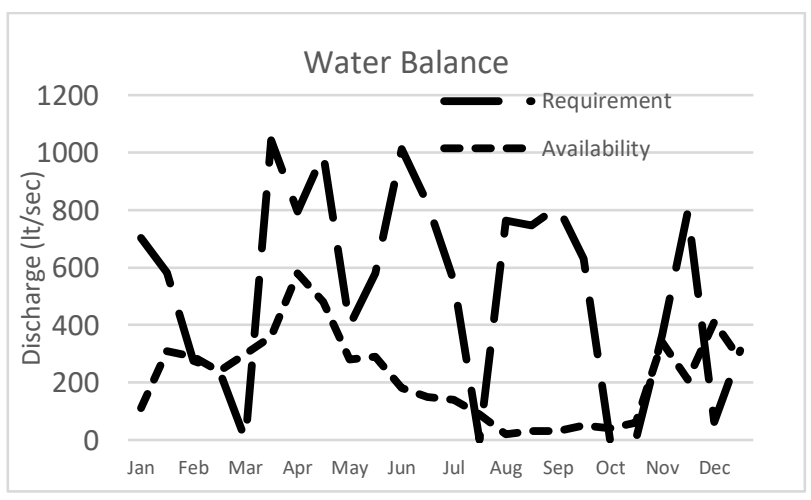

Fig. 2. Water balance for irrigation, 2017 [1].

For domestic needs, water use is taken into account from the urban and rural population in the catchment area. The reservoir location is located in a rural area so that water requirement for rural residents is $60 \mathrm{lt} / \mathrm{day} / \mathrm{capita}$ while for urban area is 120 lt/day/kapita (SNI 19-6728.12002). Estimated number of population for the next 10 years is about 13,000 lives, so the needs of raw water for communities is around $9.1 \mathrm{lt} / \mathrm{sec}$. The relationship between physical variables such as rain, temperature, 
discharge, reservoir volume, water requirements, is closely related in this analysis [11]. Climate influence can also affect water shortages [12].

\subsection{Discussion}

The availability of raw water is a major requirement to increase agricultural production, especially rice, as well as for the domestic needs of the community. The river is one of the water sources that people use to fulfill their daily needs for both agricultural and other needs. Currently one of the areas is in urgent need of raw water for domestic and irrigation purposes because the existing water has not been utilized optimally.

The reservoir location is located in the upstream area of the river with the land still covered by trees, hence the water flowing in the river is still quite clear. Field review is intended to get an overview of existing field conditions. Field review is intended to get a picture about the location of irrigation area, such as: boundary area, limit between plots, the condition of carrier system, drainage channel, measurement reference point [1].

Current conditions in the upper river areas are free intake on the left side of the river, used to irrigate rice fields but not measured properly. The rice field area served by water coming from the Cipangarangan River through an irrigation channel without a regulating door, with an average channel width of 1,2 meters and an average depth of about $25 \mathrm{~cm}$ [1]. Therefore one of the efforts is the need for a water reservoir coming from the river that can be used to irrigate rice fields and fulfill the domestic needs of local communities.

Based on topographical conditions in the area, it has the potential for the development of water sources that come from the river by making the reservoir to be used as a supply for agricultural and raw water areas, and also can increase income for the local community. By having the water reservoirs to fulfill the needs of agricultural areas, it is expected that domestic demand as well as the availability of water (water balance) [13] of the river food security programs that have been implemented by the government through the Ministry of Agriculture could be achieved. So the final goal of a righteous and prosperous society can be achieved.

Based on the results of the analysis, the watershed area at the research location is quite small, which is $6.4 \mathrm{~km}^{2}$. Since the reservoir plan is located in the upstream area of the river and the condition of the land is still covered by trees, the discharge calculated by NRECA is not too large because most of the falling rainwater is absorbed by the trees and partly absorbed into the soil. Based on the topographic condition of the local area, that are flanked by 2 hills on the left and right of the reservoir location, with the distance between hills is less than $200 \mathrm{~m}$, the area and volume taken is quite small. This is due to the average slope extending around the reservoir location, based on a measurement, is about 0.02 [1]. Based on the existing elongated slope, the downstream water elevation of the plan in the reservoir will be higher so that it will affect the higher elevation of the reservoir embankment. Based on the dependable flow of $0.6 \mathrm{~m}^{3} / \mathrm{sec}$, without taking into account the addition of the springs, the maximum irrigation area that can be irrigated is about 440 ha, so there are still some irrigated rice field areas. As for the fulfillment of raw water for the benefit of the community is also not significant because it must share with the needs of water in the fields. To achieve success in management issues, water resources management should integrate economic, social and environmental dimensions. The integration between economic, social and environmental dimensions is a manifestation of the concept of sustainable water resources management. The benefits of reservoir development are potential of increasing land area of sustainable food agriculture, increasing food production (rice), increasing labour absorption, utilizing raw water for household [1]. The resource management model should establish the integration between human and nature. This means that the physical environment and the human cultural environment are interrelated [14]. The calibration showed excellent agreement between the observed and simulated flows recorded over 30 years [15].

\section{Conclusions}

Based on the results of above analysis, the reservoir development at the research locus is considered less feasible because the dependable flow value is quite small. The relationship between water availability and demand (water balance) is not balanced. On the other hand, based on analysis of topographical conditions and local area measurements, the result is, a high elevation of embankments and development costs. The conclusion would be better if other factors were taken into account such as socio-economic analysis, geotechnical analysis and springs condition downstream of the reservoir.

\section{References}

1. PT. Winaguna Sarana Teknik, "Laporan Akhir Survey dan Pemetaan Peningkatan Air Baku Embung Nusa Indah di Kabupaten Tasikmalaya," Dinas Sumber Daya Air Provinsi Jawa Barat, Bandung, (2017)

2. Z. Hu, L. Wang, Z. Wang, Y. Hong and H. Zheng, "Quantitative Assessment of Climate and Human Impact on Surface Water Resources in Typycal Semi-Arid Watershed in The Middle Reaches of The Yellow River From 1985 t0 2006," I. J. of Climatology, vol. 35, no. 1, (2015).

3. Karlina, "Meteorological Drought Assessment in Wonogiri District," J. of Civil Engineering Forum, vol. 2, no. 2, p. 159, (2016)

4. Badan Ketahanan Pangan Kementerian Pertanian, "Rencana Strategis Badan Ketahanan Pangan Tahun 2015-2019," (Badan Ketahanan Pangan Kementerian Pertanian, Jakarta, 2015) 
5. S. Lu, W. Wang and C. Liu, "Assesment of Water Use Benefits in Irrigation District-An Application of Variable Fuzzy Model," in International Conference on Fuzzy Systems and Knowledge Discovery, (2014)

6. F. Ramadhani, "Dependable Flow and Flood Control Performance of Logung Dam. Central Java Province. Indonesia," J. of Civil Engineering Forum, vol. 3, no. 2, pp. 73-74, (2017)

7. D. Li, S. Guo and J. Yin, "Big Data Analysis Based on POT Method for Design Flood Prediction," 2016 IEEE International Conference on, (2016)

8. L. R. Ekaningtyas, "Flood Inundation Prediction of Logung River due to the Break of Logung Dam," J. of The Civil Engineering Forum, vol. 3, no. 2, p. 63, (2017)

9. S. S. Putro, "The Study of Water Quantity and Quality (Case Study: Gajahwong Watershed)," J. of The Civil Engineering Forum, vol. 2, no. 3, p. 166, (2016)

10. Y. Hardianto, "Cengklik Reservoir Performance and its Role for Drought Mitigation," J. of The Civil Engineering Forum, vol. 1, no. 3, p. 71, (2015)

11. M. Pedro-Monzonis, A. Solera, T. E. Javier and J. Paredes-Arquiola, "A Review of Water Scarcity and Drought Indexes in Water Resources Planning ang Management," J. of Hydrology, vol. 527, (2015)

12. N. Hammaouri, J. Adamowski, M. Freiwan and S. Praser, "Climate Change Impacts on Surface Water Resources in Arid and Semi-Arid Regions: a Case Study in Northern Jordan," J. Geodaetica et Geophysica, vol. 52, no. 1, (2017)

13. J. H. Song, M. S. Kang, I. Song and S. M. Jun, "Water Balance in Irrigation Reservoirs Considering Flood Control and Irrigation Efficiency Variation," J. of Irrigation and Drainage Engineering, vol. 142, no. 4, (2016)

14. D. F. Putra and N. R. Wardani, "Evaluasi Keberlanjutan Sistem Pengelolaan Sumber Daya Air "HIPPAM" Pada Masyarakat Desa Pandanrejo Kecamatan Bumiaji Batu Jawa Timur," J. Pendidikan Geografi, vol. 22, no. 1, p. 23, (2017)

15. M. Atiquzzaman and J. Kandasamy, "Prediction of Inflows From Dam Catchment Using Genetic Programming," I. J. of Hydrology Science and Technology, vol. 6, no. 2, (2016) 